\title{
Sialolithiasis in parotid gland: sialoendoscopic treatment
}

\author{
Parotis glandinda sialolitiazis: Sialoendoskopi tedavisi
}

\author{
Mehmet Akdağ \\ Department of Otolaryngology, Medical Faculty of Dicle University, Diyarbakır, Turkey
}

\begin{abstract}
Sialoendoscopy is a novel procedure for visualizing the lumen of the salivary ducts and their pathology. Sialoendoscopy has been validated for the diagnosis and treatment of non-neoplastic disorders of the salivary glands, including sialolithiasis. In this article, we present a 40 -year-old female case sialolithiasis with a parotid abscess. The diagnosis and treatment was performed endoscopically.

Key Words: Parotid diseases/diagnosis/surgery; salivary ducts/ pathology; salivary gland calculi/diagnosis/surgery.
\end{abstract}

Acute suppurative parotitis and parotid abscesses due to an obstructing sialolithiasis are rare. There are diagnostic as well as therapeutic challenges exists especially in the case of minor stones and refractory cases.

Sialoendoscopy is a new technique ${ }^{[1,2]}$ that allows almost complete exploration of the ductal system (main duct and secondary and tertiary branches). It is used to visualize the ductal system to diagnose obstructive pathologies, typically stones or rarer diseases. It can also be used as a therapeuetic tool. Besides, when sialendoscopy fails to produce an effective treatment on its own, it can be combined with additional methods such as lithotripsy techniques, minimal intraoral surgery, or external approaches.

This report presented a case of parotid abscess which had an underlying condition of sialolithiasis. With sialoendoscopy the calculus was successfully removed and the abscess was drained. The diagnostic and therapeutic aspects of the case was presented and discussed.
Sialoendoskopi, tükürük bezi kanalları ve patolojilerini görüntülemek için kullanılan yeni bir işlemdir. Sialoendoskopi, tükürük bezi taşı hastalığı dahil, tükürük bezinin tümöral olmayan hastalıklarının tanı ve tedavisinde doğrulanmıştır. Bu yazıda, parotis apsenin eşlik ettiği tükürük bezi kanal taşı hastalığ olan 40 yaşında bir kadın olgu sunuldu. Tanı ve tedavi, endoskopik olarak yapıldı.

Anahtar Sözcükler: Parotis hastalıkları/tanı/cerrahi; tükürük kanallari/patoloji; tükürük bezi taşları/tanı/cerrahi. 


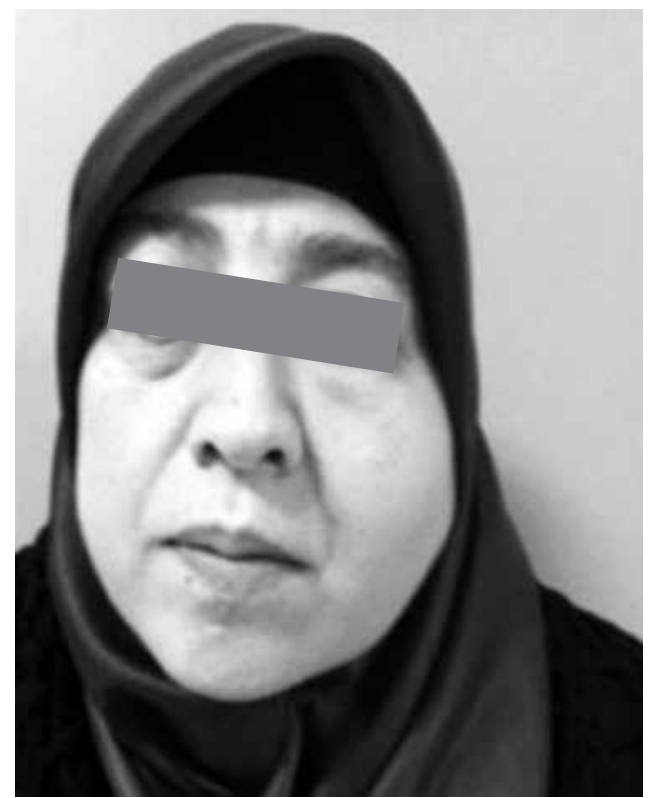

Figure 1. The mass appearance of swelling in the left parotid region.

Ultrasonographic analysis showed a large, heterogenic, hypoechoic gland. Stensen's duct orifice was dilated to nearly $3.0 \mathrm{~mm}$ in diameter, and there was a hyperechogenic focus roughly $3.0 \times 3.0 \mathrm{~mm}$ in diameter (sialolithiasis).

Sialography showed a nonspecific opacity in Stensen's duct, which was also seen on computed tomography (CT). There was gland heterogeneity and reactive cervical lymphadenopathy on CT view. The patient was treated with oral antibiotics, but she developed an

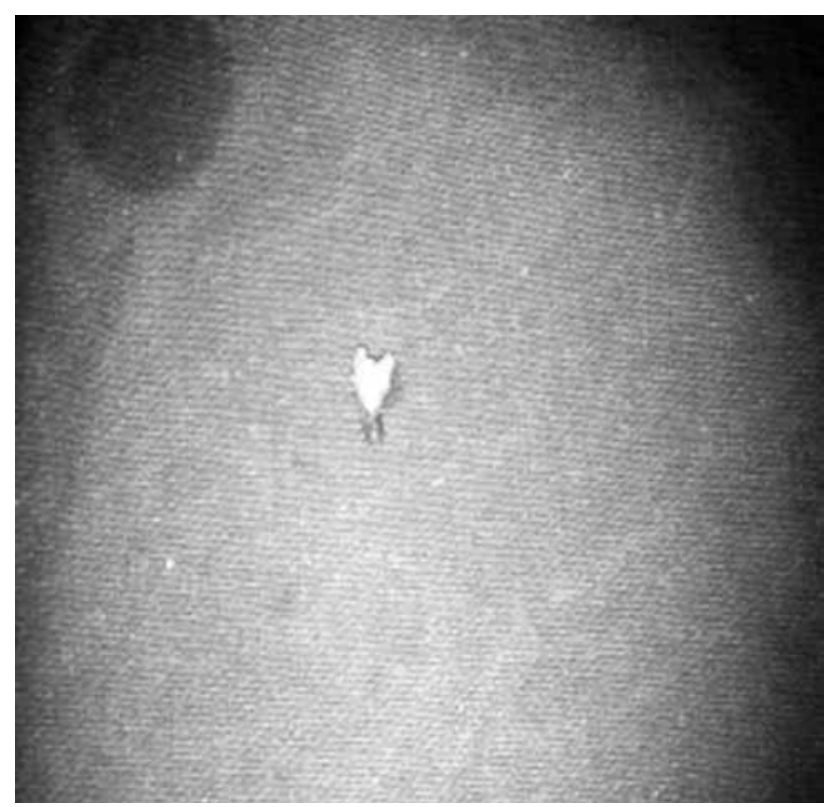

Figure 2. Image of extracted stone from the parotid stenon duct. abscess within two days. The patient was then prepared for sialendoscopy. After intravenous premedication, topical and infiltrative anesthesia [by administering xylocaine spray (10\% lidocaine), followed by applying $0.5 \mathrm{~mL}$ lidocaine hydrochloride-epinephrine solution for infiltration of the area around the papilla] the orifice was dilated with lacrimal probes and a pediatric (1-mm-Karl Storz Hopkins AG, Tuttlingen, Germany) rigid endoscope. On inserting it just $4 \mathrm{~mm}$, a mass-like stone was seen. We revealed a calculus after aspiration of the duct of gland. When the calculus (Figure 2) was removed with graspers from the main duct, $30 \mathrm{~mL}$ of purulent fluid was drained. Staphylococcus aureus was cultured from this purulent fluid. Stensen's canal was irrigated with physiological saline. On follow-up 2 and 14 days later, there was no edema or pain.

\section{DISCUSSION}

Swelling of the major salivary glands will be difficult to diagnose, despite the continual improvement of diagnostic procedures and tools. Mafee et al..$^{[3]}$ described different methods of imaging the salivary glands which included X-ray, sialography, ultrasonography (US), digital subtraction sialography (DSS), radionuclide scintigraphy, CT, magnetic resonance imaging (MRI), and sialoendoscopy. In some patients, a diagnosis cannot be made using conventional radiological studies or other diagnostic methods. ${ }^{[4-6]}$

Sialolithiasis is thought to be the most important cause of obstructive gland disease, ${ }^{[4,7,8]}$ and was found to be either the primary or secondary cause of gland swelling of unclear origin in 33\% of all patients. Ultrasonography remains an excellent primary method for detecting salivary stones, although calculi $<3 \mathrm{~mm}$ in size are

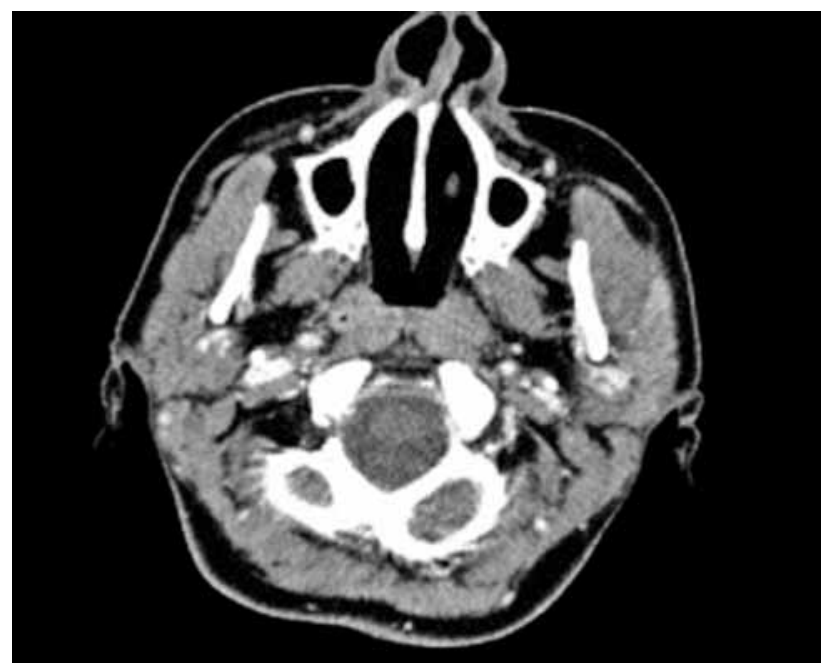

Figure 3. The heterogeneity and reactive cervical lymphadenopathy on computed tomography view. 
difficult to visualize. ${ }^{[9]}$ In the case of a minor calculus, which had a smooth consistency could not be defined clearly using conventional diagnostic methods. In this case sialendoscopy will be useful for diagnosis and treatment.

Parotid abscesses are rare; thus, there are few recent studies on this topic. Classically, they are complications of long-term debility and oral sepsis. ${ }^{[10]}$

In some patients, antibiotic therapy likely terminates early suppurative parotitis. However, once an abscess has formed, drainage is indicated. If left untreated, the infection may result in septicemia and life-threatening deep neck space infections. ${ }^{[11]}$

There are many causes of enlargement in the parotid area. Rarely, a parotid abscess with a ductal stone can cause enlargement of the parotid gland. In the case of a parotid abscess there will not be symptoms of abscess such as induration, inflammation, or fluctuance as in our case. Traditional management involves a conservative approach; however, refractory cases may require surgery ranging from papillotomy to complete gland extirpation. ${ }^{[12]}$

The classical treatment of a parotid abscess is to raise a full flap of skin, as for parotidectomy. The gland is broadly exposed and multiple incisions are made into the parotid fascia and underlying parotid gland, parallel to the branches of the facial nerve. ${ }^{[11]}$ Such radical surgery is likely to result in prolonged wound healing and cosmetically unsightly scars. Besides, surgical complications following sialoadenectomy result in other varying amounts of morbidity. These are well reported in the literature. Capaccio et al. ${ }^{[13]}$ reviewed complications following parotidectomy and described the incidence of permanent facial nerve injury (range, 1-3\%), sensory loss in the distribution of the greater auricular nerve (range, 2-100\%), and Frey syndrome (range, 8-33\%). For submandibular gland resection, the incidence of permanent marginal mandibular nerve injury (range, 1-8\%), hypoglossal nerve injury (3\%), and lingual nerve injury (2\%) are documented. Other potential complications include esthetic sequelae, salivary fistulas, sialoceles, hematomas, and wound infection. ${ }^{[13]}$

Sialendoscopy can be used as a diagnostic and therapeutic tool. Current evidence validates sialendoscopy for the treatment of non-neoplastic disorders of the salivary glands, including sialolithiasis. ${ }^{[14,15]}$ Sialolithiasis is one of the most common disorders of this type and is a major cause of sialoadenitis and unilateral diffuse swelling of the major salivary glands. ${ }^{[16,17]}$ Other common indications for sialendoscopy include the diagnostic evaluation of recurrent unexplained swelling of the major salivary glands associated with meals, ductal stenosis, and intraductal masses. ${ }^{[17,18]}$

Patients with refractory symptoms due to any salivary gland pathology that does not respond to conservative management may benefit from interventional sialendoscopy, which yields success rates of $50-70 \% .{ }^{[18,19]}$ Şerbetçi and Şengör ${ }^{[20]}$ stated that diagnostic sialendoscopy is a distinct method, which provides accurate diagnoses for all ductal disorders such as sialolithiasis. However, the total success rate of diagnosis was found to be $81.6 \%$ in their study by using this method. Consequently, with the use of sialoendoscopy surgery and related morbidity incision, scar, nerve damage, risk of bleeding etc. can be avoided. The patient recover quickly when compared with other therapeutic methods.

In conclusions, classical methods for investigating the salivary glands and parotid enlargement include radiography using $\mathrm{X}$-rays, US, CT, sialography, MRI, and sialendoscopy. At times, the diagnosis of parotid enlargement is difficult. It is also difficult to remove parotid stones and drain parotid abscesses using classical methods. Sialendoscopy is safe, effective, and minimally invasive and has been proved effective for both the diagnosis and management of obstructive parotid gland disorders.

\section{Declaration of conflicting interests}

The authors declared no conflicts of interest with respect to the authorship and/or publication of this article.

\section{Funding}

The authors received no financial support for the research and/or authorship of this article.

\section{REFERENCES}

1. Marchal F, Dulguerov P, Lehmann W. Interventional sialendoscopy. N Engl J Med 1999;341:1242-3.

2. Marchal F, Becker M, Dulguerov P, Lehmann W. Interventional sialendoscopy. Laryngoscope 2000;110:318-20.

3. Mafee MF, Valvassori GE, Becker M. Imaging of the head and neck. 2nd ed. Stuttgart: Thieme publications; 2005.

4. Rice DH. Noninflammatory, non-neoplastic disorders of the salivary glands. Otolaryngol Clin North Am 1999;32:835-43.

5. Zenc J, Iro H. Die Sialolithiasis und deren Behandlung. Larygo-Rhino-Otol 2001;80(Suppl):115-36.

6. Iro H, Uttenweiler V, Zenk J. Kopf-Hals-sonografie. Berlin Heidelberg: Springer; 2000.

7. Marchal F, Dulguerov P, Becker M, Barki G, Disant F, Lehmann W. Specificity of parotid sialendoscopy. Laryngoscope 2001;111:264-71. 
8. Marchal F, Dulguerov P, Becker M, Barki G, Disant F, Lehmann W. Submandibular diagnostic and interventional sialendoscopy: new procedure for ductal disorders. Ann Otol Rhinol Laryngol 2002;111:27-35.

9. Marchal F, Dulguerov P. Sialolithiasis management: the state of the art. Arch Otolaryngol Head Neck Surg 2003;129:951-6.

10. Krippaehne WW, Hunt TK, Dunphy JE. Acute suppurative parotitis: a study of 161 cases. Ann Surg 1962;156:251-7.

11. Boland J. The surgery of sepsis: parotid abscess. In: King M, Bewes P, Cairns J, Thornton J, Nundy S, editors. Primary surgery. Volume One: Non-Trauma. Oxford: Oxford University Press; 1990. p. 435-6.

12. Marchal F, Kurt AM, Dulguerov P, Lehmann W. Retrograde theory in sialolithiasis formation. Arch Otolaryngol Head Neck Surg 2001;127:66-8.

13. Capaccio $\mathrm{P}$, Torretta S, Pignataro L. The role of adenectomy for salivary gland obstructions in the era of sialendoscopy and lithotripsy. Otolaryngol Clin North Am 2009;42:1161-71, Table of Contents. doi: 10.1016/j. otc.2009.08.013.

14. Nahlieli O, Baruchin AM. Sialoendoscopy: three years' experience as a diagnostic and treatment modality. J Oral Maxillofac Surg 1997;55:912-8.

15. Luers JC, Grosheva M, Reifferscheid V, Stenner M, Beutner D. Sialendoscopy for sialolithiasis: early treatment, better outcome. Head Neck 2012;34:499-504. doi: 10.1002/ hed.21762.

16. Marchal F, Dulguerov P. Sialolithiasis management: the state of the art. Arch Otolaryngol Head Neck Surg 2003;129:951-6.

17. Nahlieli O, Nakar LH, Nazarian Y, Turner MD. Sialoendoscopy: A new approach to salivary gland obstructive pathology. J Am Dent Assoc 2006;137:1394-400.

18. Walvekar RR, Razfar A, Carrau RL, Schaitkin B. Sialendoscopy and associated complications: a preliminary experience. Laryngoscope 2008;118:776-9. doi: 10.1097/ MLG.0b013e318165e355.

19. Kim JW, Han GS, Lee SH, Lee DY, Kim YM. Sialoendoscopic treatment for radioiodine induced sialadenitis. Laryngoscope 2007;117:133-6.

20. Serbetci E, Sengor GA. Sialendoscopy: experience with the first 60 glands in Turkey and a literature review. Ann Otol Rhinol Laryngol 2010;119:155-64. 